\title{
CHRZEST JEZUSA W EWANGELII WEDŁUG ŚW. MARKA (1,9-11) A IDEA SAMOUNIŻENIA SIĘ BOGA. PRZYCZYNEK DO CHRYSTOLOGII DRUGIEJ EWANGELII
}

Kardynał Christoph Schönborn w swojej monografii Bóg zestał Syna Swego. Chrystologia spojrzał na prawdę o wcieleniu Syna Bożego w kluczu samouniżenia się Boga i wyniesienia człowieka ${ }^{1}$. Autor zauważa: „Obie linie: samouniżenie się Boga (descensus) i wyniesienie człowieka (ascensus), mają swój punkt przecięcia, a jest nim Wcielenie" ${ }^{\prime 2}$. Ideę samouniżenia się Boga przeczuwaną w Starym Testamencie czy myśli judaistycznej podejmuje bardzo wyraźnie Nowy Testament ${ }^{3}$. W tym kluczu można by spojrzeć nie tylko na moment $\mathrm{z}$ życia Jezusa sformułowany w Credo: „Począł się z Ducha Świętego - narodził się z Maryi dziewicy - stał się człowiekiem", ale także na całą działalność Jezusa Chrystusa. Biskup Wiednia uważa, że prawdę o wcieleniu Syna Bożego należy traktować

${ }^{*}$ Ks. Dariusz Kotecki - licencjat nauk biblijnych, dr hab. teologii w zakresie biblistyki, prof. UMK, Dziekan Wydziału Teologii i kierownik Katedry Biblistyki Wydziału Teologicznego UMK w Toruniu.

${ }^{1}$ Ch. Schönborn, Gott sandte seinen Sohn. Christologie, Milano 2001, tłum. polskie: Bóg zestat swego Syna. Chrystologia, Poznań 2002, s. 113nn.

2 Tamże, s. 125.

3 Tamże, s. 113-125. 
jako: „pradaną chrystologii, co oznacza konkretnie, że powinniśmy rozważać życie i Osobę Jezusa jako Boga Wcielonego"4. Czytelnik Biblii na dowód istnienia idei samouniżenia się Boga w Nowym Testamencie przytoczyłby na pewno teksty mówiące o dziewiczym poczęciu Jezusa Chrystusa z Ducha Świętego (por. Mt 1,18.20 i Łk 1,35). W kontekście tej idei można spojrzeć również na tekst o kenozie Syna Bożego z Flp 2,5-11. Wydaje się, że idea samouniżenia się Boga Jedynego w Jezusie Chrystusie jest także kluczem do zrozumienia chrystologii najstarszej Ewangelii, tj. Ewangelii według św. Marka, której dane chrystologiczne chyba najbardziej zbliżają nas do Jezusa historycznego. Próżno w tej Ewangelii szukać prawdy o dziewiczym poczęciu Jezusa Chrystusa, którą podają pozostali synoptycy (Mt 1,18nn.; Łk 1,26nn.). Cała działalność Jezusa zostaje przez ewangelistę obramowana dwoma wydarzeniami: chrztem Jezusa w Jordanie (Mk 1,9-10) oraz Jego śmiercią na krzyżu $(15,33)$. Jedno i drugie wydarzenie łączy fakt, że ewangelista patrzy na obydwa jako na chrzest (por. 1,9; 10,38). Od samego początku swojej Ewangelii Marek zadaje podstawowe pytanie chrystologiczne, które wydaje się najważniejszą kwestią Ewangelii: Kim jest Jezus? Wynika to już z samego pierwszego wiersza, który za większością badaczy można potraktować jako tytuł całego dzieła, streszczającego Ewangelię, ale także określającego jej cel: „Początek Dobrej Nowiny o Jezusie Mesjaszu Synu Bożym" $(1,1)$. Cała Ewangelia zmierza do tego, aby przedstawić Jezusa jako Mesjasza i Syna Bożego, a więc jej celem jest doprowadzenie czytelnika do wiary $\mathrm{w}$ takiego właśnie Jezusa. W całej narracji Markowej padają również wprost pytania chrystologiczne (por. 1,27; 4,40), które są otwarte i domagają się odpowiedzi ze strony słuchaczy czy czytelników Ewangelii. Chrystologia najstarszej Ewangelii, podobnie jak innych pism Nowego Testamentu, jest narracyjna. Nie jest to chrystologia orzeczeń dogmatycznych. Jako narracja musi być interpretowana. W fundamentalne pytanie chrystologiczne drugiej Ewangelii wpisuje się także opis chrztu Jezusa w Jordanie (Mk 1,9-11). Jest on pierwszą narracją, wprowadzającą bezpośrednio na scenę opisywanych wydarzeń Jezusa Chrystusa. Można przypuszczać, że ma ona zarazem fundamentalne znaczenie dla zrozumienia całej chrystologii Marka. Wydaje się, że kluczem do zrozumienia tej krótkiej perykopy może być idea samouniżenia się Boga. Nie jest to idea narzucona perykopie z zewnątrz. Znajdują się bowiem w tekście Mk 1,9-11, odczytanym w jego kontekście literackim, elementy, które można

${ }^{4}$ Tamże, s. 124. 
zrozumieć tylko w kluczu tej idei. W niniejszym artykule, dokonując analizy egzegetycznej Mk 1,9-11, wskażemy te elementy, które według nas świadczą o obecności takiej idei. Jak uważa F. Lentzen-Deis, opis chrztu Jezusa tworzy gatunek zwany „wizją objaśniającą”, na którą składają się następujące części: 1) przedstawienie osoby $(1,9) ; 2)$ wprowadzenie wizji $(1,10 a) ; 3)$ treść wizji $(1,10 b c) ; 4)$ wprowadzenie audycji $(1,11 a)$; 5) treść audycji $(1,11 b)^{5}$. Na potrzeby naszego artykułu uprościliśmy ten schemat do trzech punktów: 1) Jezus z Nazaretu przychodzi (= przedstawienie osoby); 2) Jezus zobaczył (= wprowadzenie do wizji oraz treść wizji); 3) „Tyś jest mój Syn umiłowany” (= wprowadzenie audycji oraz treść audycji).

\section{JEZUS Z NAZARETU PRZYCHODZI $(1,9)$}

Cała scena rozpoczyna się od wprowadzenia: "i stało się w tych dniach, przyszedł Jezus z Nazaretu w Galilei” (1,9). Wyrażenie: „i stało się w tych dniach" (kai egeneto en ekeinais tais hēmerais), które notuje wśród synoptyków tylko Marek (por. Mt 3,13; Łk 3,21), może odnosić się zarówno do Janowej zapowiedzi przyjścia "silniejszego od niego" $(1,7)$ i staje się uroczystym wprowadzeniem na scenę Jezusa ${ }^{6}$, jak i może być zwyczajnym podjęciem czasowym po jakimś, bliżej nieokreślonym, odcinku czasowym lub też może mieć zabarwienie eschatologiczne: „wyraża ono początek i nowy etap $\mathrm{w}$ historii relacji Boga $\mathrm{z}$ ludźmi, etap decydujący i końcowy"7, związany z przyjściem "silniejszego” od Jana Chrzciciela (por. erchetai w 1,7 i èlthen w 1,9). Kontekst zdania sugeruje, że chodzi w tym miejscu o całą działalność Jana Chrzciciela. Autor jednak podkreśla w narracji, że od owego "stało się w owych dniach” w 1,9 zaczyna się coś nowego. Po informacji o wystąpieniu Jana w 1,4 (egeneto Iōannēs)

5 F. Lentzen-Deis, Die Taufe Jesu nach den Synoptikern. Literarkritische und gattungsgeschichtliche Untersuchung, FTS 4, Frankfurt am Main 1970, s. 195-197, 249-289. Najnowszą monografią na temat chrztu Jezusa z perspektywy czterech ewangelistów jest: A. Malina, Chrzest Jezusa w czterech Ewangeliach. Studium narracji $i$ teologii, "Studia i Materiały Wydziału Teologicznego Uniwersytety Śląskiego" 34, Katowice 2007.

${ }^{6}$ R. H. Gundry, Mark. A Commentary on His Apology for the Cross, Grand Rapids 1992, s. 47. A. Malina, dz. cyt., s. 183 (autor uważa, że „Rozbudowane określenie odnosi się do całej działalności Jana na pustyni. Przedstawione po nim wydarzenia nie są umieszczone w jakimś precyzyjnie określonym momencie tej działalności").

7 S. Légasse, Marco, Roma 2000, s. 72. Przeciwny: A. Malina, dz. cyt., s. 185. 
pojawiają się formy czasownikowe $\mathrm{w}$ imperfectum: ekseporeueto, ebaptidzonto $(1,5), \bar{e} n[\ldots]$ endedumenos $[\ldots]$ kai esthiōn $(1,6)$, ekēryssen $(1,7)$. Nie chodzi zatem o opis pojedynczych wydarzeń związanych z działalnością Jana, ale o całościowe przedstawienie tej aktywności. Od 1,9 mówi się już o pojedynczych wydarzeniach, stąd zostały zastosowane orzeczenia w trybie oznajmującym aorystu: èlthen, ebaptisthe $(1,9)$, eiden, egeneto $(1,11)$. Nie jest wykluczone, że formuła „stało się w owych dniach", mimo że nie przywołuje treści eschatologicznych, jak to mamy w jej zastosowaniu w Mk 13,17.24, może wskazywać na nowy etap relacji między Bogiem i ludźmi. Kontekst bezpośredni ukaże, na czym będzie polegać owa nowość relacji Boga z ludźmi ${ }^{8}$.

Pierwszy raz w Mk Jezus staje się podmiotem orzeczenia (ēlthen) wyrażonego za pomocą czasownika ruchu (erchomai): „Przyszedł Jezus z Nazaretu w Galilei i przyjął chrzest od Jana w Jordanie" $(1,9)$. Samo wyrażenie apo Nazaret tēs Galilaias nie musi koniecznie oznaczać dopełnienia czasownika ruchu èlthen (= „Jezus przyszedł z Nazaretu") cyfikację imienia Jezus (= „Jezus z Nazaretu przyszedł"), jak np. w 15,43: „Józef z Arymatei"10. Nazwa miejscowości Nazaret, całkowicie pominiętej przez Stary Testament, Józefa Flawiusza, Talmud czy midrasze, która leżała w pobliżu szlaku handlowego z Egiptu do Damaszku i należała do miejscowości mało znaczących w czasach Nowego Testamentu, nie

${ }^{8}$ W Mk we wszystkich przypadkach, w których występują te dwa wyrażenia, na początku narracji $\mathrm{w}$ odpowiednich perykopach zostaje podkreślona pewna nowość. W 2,23 (początek perykopy 2,23-28) ta nowość zasadza się na stwierdzeniu końcowym: "Zatem Syn człowieczy jest Panem szabatu” $(2,28)$. W 8,1, który to wiersz rozpoczyna perykopę o drugim rozmnożeniu chleba $(8,1-9)$, ta nowość może być upatrywana w samoobjawieniu się Jezusa. Podczas gdy w pierwszej scenie rozmnożenia chleba $(6,34-44)$ sam narrator informuje czytelnika o tym, że Jezus: „odczuł miłosierdzie (esplagchnisthē) nad nimi, bo byli jak owce niemające pasterza", w drugiej scenie sam Jezus mówi do uczniów: „Odczuwam miłosierdzie (splagchnidzomai) nad ludem”. Mk 13,17.24 są tekstami o wyraźnym zabarwieniu eschatologicznym.

9 Tak już: E. Klostermann, Das Markusevangelium, HNT 3, Tübingen ${ }^{4} 1950$, s. 8; V. Taylor, The Gospel according to St. Mark. The Greek Text with Introduction, Notes and Indexes, London '21966, s. 159; J. Gnilka, Marco, Assisi 1987, s. 52; R. H. Gundry, dz. cyt., s. 47 .

${ }^{10}$ Brak rodzajnika przed imieniem "Jezus" pozwala przypuszczać, że narrator pragnie przedstawić bohatera swego opowiadania jako nieznanego swoim czytelnikom. Stąd wyrażenie „z Nazaretu” mogłoby być uważane za pierwsze możliwe określenie bohatera. Tak: E. Manicardi, Il cammino di Gesủ nel Vangelo di Marco. Schema narrativo e tema cristologico, AnBib 96, Roma 1981, s. 52. A. Malina, dz. cyt., s. 194, łączy ściśle orzeczenie "przyszedł" z podmiotem Jezus. 
pojawia się więcej w Mk, chyba że w określeniu Jezusa jako Nazarejczyka, nadzarēnos (por. 1,24; 10,47; 14,67; 16,6) ${ }^{11}$. Galilea będzie miejscem, w którym Jezus zainauguruje swoją działalność publiczną $(1,14)$. Te określenia mówią nam o ziemskiej historii Jezusa. W miejscowości dalekiej od Jerozolimy, niejako na uboczu, wyrosła konkretna osoba o imieniu Jezus.

Jezus przychodzi w celu przyjęcia od Jana chrztu w Jordanie: „i przyjął chrzest w Jordanie od Jana”. Ważnym punktem odniesienia staje się dla naszej perykopy opis całej działalności Jana Chrzciciela $(1,2-8)^{12}$, na którą składają się dwie równoległe czynności, wyrażone za pomocą dwóch imiesłowów: udzielanie chrztu wodą na pustyni (baptidzōn) oraz głoszenie (kēryssōn) chrztu nawrócenia dla odpuszczenia grzechów $(1,4)$. Adresaci działalności Jana zostają przedstawieni w kolejnym wierszu: „I przychodziła do niego cała judzka kraina oraz wszyscy mieszkańcy Jerozolimy i byli chrzczeni przez niego w rzecze Jordan, wyznając swoje grzechy" (1,5). Narrator skupia się tutaj na pierwszej czynności Jana, tj. chrzczeniu, któremu towarzyszy wyznawanie grzechów ${ }^{13}$. W tym opisie brakuje jakiejkolwiek wzmianki o odpuszczeniu grzechów. Marek przechodzi w kolejnych wierszach do opisu ubierania się Jana, jego odżywiania oraz Jego głoszenia (1,7-8). Ta ostatnia czynność jest wyrażona za pomocą orzeczenia $\mathrm{w}$ imperfectum: ekēryssen. Z punktu widzenia narracji wydaje się, że od w. 1,5 mamy do czynienia z uszczegółowieniem opisu podwójnej działalności Jana: imiesłowowi baptidzōn z 1,4 odpowiada orzeczenie $\mathrm{w}$ imperfectum ebaptidzonto w 1,5, natomiast imiesłowowi kēryssōn z 1,4 odpowiada orzeczenie w imperfectum ekēryssen w 1,7. Skutkiem chrztu udzielanego przez Jana, któremu towarzyszyło wyznawanie grzechów, nie było ich odpuszczenie. Jego chrzest nie był chrztem dla odpuszczenia grzechów. Gdyby taki był, to niepotrzebne byłoby przyjście silniejszego od Jana oraz chrzczenie w Duchu Świętym. Chrztem na odpuszczenie

${ }^{11}$ W perykopie Mk 6,1-6, którą komentatorzy nazywają zazwyczaj: „Odrzucenie Jezusa w Nazarecie", ewangelista mówi o ojczyźnie Jezusa (patris).

${ }^{12}$ Niektórzy badacze wyłączają wiersze 1,2-3 z opisu działalności Jana Chrzciciela, traktując je jako prolog do Markowej narracji (por. R. Bauckham, Jesus and the God of Israe. God Crucified and Other Studies on the New Testament's Christology of Divine Identity, Grand Rapids-Cambridge 2008, s. 265). Za większością badaczy powinno się łączyć 1,2-3 z 1,4-8 w kluczu "zapowiedź - wypełnienie". Wiersz 1,1 jest tytułem całej Ewangelii.

${ }^{13} \mathrm{~W}$ zdaniu mamy konstrukcję, w której spotykamy dwa razy orzeczenia w imperfectum: eksporeueto i ebaptidzonto oraz raz imiesłów eksomologoumenoi. Orzeczenia wyrażają czynność pierwszoplanową. Natomiast czynność wyrażona w imiesłowie jest podporządkowana drugiemu orzeczeniu, co oznacza, że wyznawanie grzechów towarzyszyło chrztowi w Jordanie. 
grzechów będzie dopiero chrzest w Duchu Świętym, który będzie udzielany przez silniejszego od Jana: „Jan głosił: «Idzie za mną mocniejszy ode mnie, któremu nie jestem godzien, aby schylić się i rozwiązać rzemyka u Jego sandałów»" $(1,7)$. Wyznawanie grzechów, towarzyszące chrztowi Janowemu, jest aktem stawania w prawdzie. Wyznający grzechy dostrzegają, że ich relacja do Boga jest niewłaściwa i wymaga naprawy, której oni sami dokonać nie mogą (2,7). Potrzebują wewnętrznego oczyszczenia, które może dać im tylko Ten, którego Jan zapowiada. Obmycie wodą z Jordanu nie usuwa grzechów. Wskazuje najwyżej na dyspozycyjność tych, którzy je otrzymują, do przyjęcia "chrztu w Duchu Świętym”, które może usunąć wyznawane grzechy. Jest to innymi słowy dyspozycja do przyjęcia Tego, który takiego chrztu będzie udzielać. W świetle tego, co powiedzieliśmy, staje się jasny cel pojawienia się Jana Chrzciciela. Cała jego działalność zmierza do ujawniania prawdy o negatywnej relacji ludzi do Boga i jednocześnie niemożności naprawienia jej ludzkimi siłami oraz objawienia im nadejścia osoby, która jest zdolna tę relację naprawić. Czytelnik może w tym miejscu zadać sobie pytanie, dlaczego Ten, którego Jan zapowiada, jest zdolny do naprawienia tej relacji. Dalsza część narracji będzie starała się odpowiedzieć na to pytanie.

Wracając do naszego tekstu, nie możemy nie zauważyć związku Jezusowego êlthen z głoszonym przez Jana Chrzciciela przyjściem (por. erchetai w 1,7) „silniejszego od niego". Siła tego, który ma przyjść, wynika z faktu, że Jan chrzci tylko wodą, Ten zaś będzie chrzcił (zanurzał) w Duchu Świętym. Dopiero ten chrzest będzie prowadził do rzeczywistego odpuszczenia grzechów, które może być tylko dziełem samego Boga (por. 2,7; 3,28; 11,25) $)^{14}$.

Na wyższość Tego, który ma przyjść, trzeba jednak popatrzeć jeszcze z innej perspektywy, znanej zarówno ewangeliście, jak i czytelnikowi. Wystąpienie Jana na pustyni jest widziane jako początek spełniania przez Boga zapowiedzi o posłaniu zwiastuna i wołaniu głosu na pustyni:

Jak jest napisane u Izajasza proroka: „Oto posyłam wysłańca mojego przed Tobą. Ten przygotuje drogę Twoją. Głos wołającego na pustyni: Przygotujcie drogę Panu, prostymi czyńcie ścieżki Jego" $(1,2-3)$.

${ }^{14}$ Dokładne porównanie znaczenia dwóch chrztów, tj. Janowego i Jezusowego, czytelnik znajdzie w: A. Malina, dz. cyt., s. 205-214. 
Ten tekst jest niezwykle ważny dla całej chrystologii. Formuła wprowadzająca katchōs gegraptai jest formułą klasyczną, która znajduje się zarówno w LXX (4 Krl 14,6; 23,21; 2 Krn 23,18; 25,4; Tb 1,6; Dn 9,13), jak i NT (Łk 2,23; Dz 7,42; 15,15; Rz 1,17; 3,10). W Mk spotykamy ją jeszcze dwa razy $(9,13 ; 14,21 ;$ por. 7,6$)$. W Mk 1,2 cytacja jest przyporządkowana Izajaszowi. W rzeczywistości jednak tylko druga część $(1,3)$ pochodzi z tej księgi. Pierwsza natomiast: „Oto posyłam anioła mojego przed tobą, ten przygotuje drogę przed tobą" $(1,2 \mathrm{~b})$ nie znajduje analogii w żadnym tekście ST. Możemy jedynie mówić o aluzji do Ml 3,1, z dużym wpływem Wj 23,20. Ten cytat ma swoje paralele w Mt 11,10; Łk 7,27. U pozostałych synoptyków nie zostaje umieszczony w innym kontekście. Kontekst Markowy nie wydaje się przypadkowy. Przesłanie zostaje skierowane do kogoś, stąd zaimek "ty". Jest to niejako dyskurs skierowany do kogoś. W Wj 23,20 czytamy: „Oto ja poślę mojego wysłańca przed tobą". Jest to wyrocznia skierowana do ludu Izraela, któremu Bóg obiecuje swojego posłańca, mającego poprowadzić lud do ziemi Kanaan. W Mk jednak z całego kontekstu wynika, że tekst jest bardziej podporządkowany Ml 3,1: „Oto ja poślę wysłannika mego, aby przygotował drogę przede mną", gdzie Bóg zapowiada swoje przybycie w „dzień Pański”. W Mk 1,1 Bóg zwraca się do tego, który przyjdzie. Wyjątkowość tego przyjścia objawia się $\mathrm{w}$ tym, że zostaje ono przygotowane przez pojawienie się wysłańca Boga (angelos mou), podobnie jak w przypadku przyjścia samego YHWH. Ten fragment objawia nam natychmiast, kim jest ten, który przyjdzie. Nigdy żaden prorok nie był poprzedzony przez jakiegoś wysłańca, który przygotowałby jego przyjście. Tylko przyjście Boga poprzedzali wysłańcy. Druga cytacja pochodzi z Iz 40,3. Między tymi dwiema cytacjami w Mk 1,2-3 zachodzi ścisły paralelizm: „droga twoja” (hodos sou) z 1,2 jest „drogą Pana" (odos kyriou) z 1,3. W Tekście Masoreckim (TM) głos krzyczy "Na pustyni przygotujcie drogę dla YHWH. Wyprostujcie na pustkowiu ścieżkę dla naszego Boga". W LXX słowo kyrios zastępuje imię samego Boga z TM. Tekst LXX jest zbliżony do naszego. W 1,4 z pojawieniem się Jana Chrzciciela zaczyna spełniać się zapowiedź z 1,2-3. W momencie, kiedy zapowiada on przyjście silniejszego od niego, który idzie po nim, staje się jasne, że Jan jest owym wysłańcem (angelos mou) z 1,2, który ma przygotować drogę. W 1,9 pojawia się ten, dla którego ta droga została przygotowana. W świetle 1,9 staje się oczywiste, że w 1,2-3 autor aplikuje do Jezusa teksty starotestamentowe, które używają Bożego imienia (Panem jest Jezus, prekursorem Jan Chrzciciel). To Boże imię nie odnosi się do boskich funkcji, ale do jedynej boskiej tożsamości. Ewangelista 
podkreśla w ten sposób, że Jezus uczestniczy w tej jedynej tożsamości samego Boga ${ }^{15}$. Wydaje się, że jest to najlepszy komentarz w Mk do Jezusowego tytułu "Syn Boży”. Odpowiada on na pytanie, w jakim sensie Jezus jest Synem Bożym. Nie można jednak zapomnieć, że z cytowanego proroctwa wynika jasne rozróżnienie osób: Boga i Jezusa. Podmiotem wypowiedzi jest Bóg, jej adresatem zaś Jezus.

Jezus przyjmuje chrzest $\mathrm{w}$ rzece Jordan od Jana. Jakie jest znaczenie tego aktu? Narrator nie przez przypadek nie umieszcza Jezusa wśród adresatów działalności Jana. Nie ma Go wśród tych, o których mówi Jan, używając zaimka "wy": "Ja was chrzciłem w wodzie, Ten zaś będzie was chrzcił w Duchu Świętym" $(1,8)$. Jezus różni się od adresatów pochodzeniem, oddzielnym przyjściem oraz faktem, że jest czynnym podmiotem chrzczenia w Duchu Świętym. Między chrztem udzielonym przez Jana grzesznikom a chrztem udzielonym Jezusowi nie zachodzi ścisły paralelizm, Jezus bowiem według narracji nie wyznaje grzechów. Bardziej naturalna wydawałaby się następująca sekwencja zdarzeń: jakiś Jezus z Nazaretu przychodzi, staje pośród grzeszników (tym samym uznaje siebie za grzesznika), aby przyjąć taki sam jak oni chrzest nawrócenia, wyznając przy tym swoje grzechy. Taką sekwencję można by różnie zinterpretować: „Jezus wyznał grzechy, ponieważ był grzesznikiem; wyznał je, ponieważ nie był świadomy swojej bezgrzeszności; wiedział o swojej bezgrzeszności, ale przez wyznanie grzechów solidaryzował się z grzesznikami, stanął po ich stronie, a nawet - jak to później zinterpretują nowotestamentowe teksty przywołujące fragmenty czwartej pieśni o słudze Jahwe - zajął ich miejsce"16. Nie wydaje się, aby odpowiedź na pytanie, czy Jezus miał świadomość, czy też nie, swojej bezgrzeszności, stała u podstaw opisania przez ewangelistę chrztu Jezusa w Jordanie. Bez wątpienia Jezus przyjmuje ten sam chrzest, który przed Nim przyjmowali grzesznicy z ziemi judzkiej i Jerozolimy. Nie przekonują nas argumenty A. Maliny, który podkreśla różnicę między Jezusem i pozostałymi ochrzczonymi:

Wydarzenia, które następują bezpośrednio po przyjęciu chrztu, wskazują na istotną różnicę między Jezusem a pozostałymi ochrzczonymi przez Jana. Zamiast wyznawania grzechów następuje działanie zaadresowane

${ }_{15}$ Por. R. Bauckham, dz. cyt., s. 265.

16 A. Malina, dz. cyt., s. 215. 
do Jezusa. Objawiają one Jego relację do Boga, która nie potrzebuje żadnego doskonalenia, uzupełnienia czy naprawy. Analogia z wyznaniem grzechów polega na tym, że również w tym przypadku relacja człowieka do Boga stanowi przedmiot pewnego rodzaju poznania, którego podmiotem jest osoba przyjmująca chrzest od Jana. W ten sposób wydarzenia po chrzcie Jezusa są zbieżne $\mathrm{z}$ aktem towarzyszącym przyjmowaniu chrztu w Jordanie przez innych ludzi. W obydwu przypadkach chodzi o poznanie prawdy o relacji ochrzczonych do Boga. Na tym poziomie chrzest w Jordanie ma jednakowe znaczenie dla wszystkich, którzy go przyjmowali od Jana: zarówno dla mieszkańców ziemi judzkiej i Jerozolimy, jak i dla Jezusa ${ }^{17}$.

Egzegeta nie zauważa, że wyznawanie grzechów przez przyjmujących chrzest od Jana nie jest wydarzeniem po chrzcie, ale jest aktem, towarzyszącym chrztowi. Oni, wychodząc (mamy w 1,5 użyty czasownik eksporeuomai, w którym przedrostek ek sugeruje ideę odseparowania o czegoś) ze swoich miejsc zamieszkania i przychodząc do Jana, już uznają się za grzeszników. Wyznawanie grzechów w czasie chrztu jest dopełnieniem aktu uznania, że ich relacja do Boga jest niewłaściwa.

Z opisu wydarzenia chrztu można wywnioskować, że Jezus jest przedstawiony jako ten, który miał samoświadomość swojej odmiennej relacji do Boga jeszcze przed przyjęciem chrztu. Podobnie pierwszy cytat starotestamentowy w 1,2, w którym, jak zauważyliśmy, Bóg oznajmia swojemu Synowi wysłanie zwiastuna, sugeruje, że w myśli ewangelisty Jezus, w porównaniu z innymi ludźmi, od samego początku, miał świadomość odmienności swojej relacji z Bogiem i dlatego w konsekwencji nie przychodzi On ze wszystkimi wyznającymi grzechy, nie jest też adresatem obietnicy przyszłego chrztu w Duchu Świętym. Jezus nie uznaje siebie za grzesznika, potrzebującego oczyszczenia. Teofania, która nastąpi po chrzcie, nie może być traktowana jako źródło świadomości Jezusa o Jego bezgrzeszności i mesjańskiej godności. Na akt przyjścia i przyjęcia chrztu należy spojrzeć - wbrew temu, co mówi Malina - w kluczu solidarności Jezusa nie tyle z grzesznikami jako takimi, ile z tymi, którzy uznają swoją relację do Boga za niewłaściwą. Dopiero takie uznanie może prowadzić ludzi do zwrócenia się do Tego, który jest w stanie tę relację z Bogiem naprawić. Wydaje się, że nie przez przypadek autor, mówiąc o chrzcie Jezusa, określa go jako eis ton Iordanēn, a nie jak to mamy

${ }^{17}$ Tamże, s. 215-216. 
$\mathrm{w}$ 1,5 w odniesieniu do grzeszników - en tō Iordanēe. Z uwagi na częste zamienne stosowanie przez Marka przyimków en i eis $(1,39 ; 13,3,9.16$; 14,9) można by obydwa wyrażenia potraktować jako synonimiczne. Być może jednak narrator w przypadku Jezusa chce zwrócić uwagę na Jego zanurzenie w Jordanie, stąd używa przyimka eis, który wskazuje na cel, kierunek. Jezus wchodzi do Jordanu po wszystkich, którzy przed nim przyjmowali chrzest (po tym wydarzeniu narrator nie wspomina chrztu nikogo innego). W ten sposób zostaje podkreślona relacja Jezusa do tych, którzy przyjmowali chrzest. On stoi po ich stronie. W Jego chrzcie mamy do czynienia z symbolicznym gestem zanurzenia się nie tyle w wodach Jordanu, ile w grzechach tych, którzy przyjmowali chrzest w Jordanie. Ewangelista ukazuje Jezusa w jego relacji do ludzi, aby potem przejść do ukazania Jego relacji do Boga i tym samym odpowiedzenia na pytanie, które interesuje słuchaczy i czytelników Ewangelii: dlaczego Ten, którego zapowiedział Jan, będzie mógł chrzcić w Duchu Świętym i tym samym odpuszczać grzechy? W następującej po chrzcie teofanii bezpośrednio zostaje dopełnione to, co pośrednio wyraził ewangelista rozwojem narracji. Jezus jest tym, którego relacja do Boga jest doskonała, ponieważ jest Synem Bożym, uczestniczącym w boskiej tożsamości samego YHWH.

Na przyjście Jezusa trzeba patrzeć także w kontekście całej Ewangelii Marka, w której ruch Jezusa ściśle łączy się z Jego misją. Czasowniki ruchu, lokalizacje geograficzne nie tylko wyznaczają schemat narracyjny Ewangelii, ale również odzwierciedlają jej temat chrystologiczny. Ziemska wędrówka Jezusa jest realizacją, konkretyzacją drogi Bożej ${ }^{18}$. Pierwsza wzmianka o przyjściu Jezusa zaznacza początek Jego działalności. Kolejne wzmianki, w których spotkamy czasownik erchomai w odniesieniu do Jezusa, wskażą na cel Jego przyjścia i zostanie w nich użyta forma trybu oznajmującego z bezokolicznikami (por. 1,$24 ; 2,17 ; 10,45)^{19}$. W swojej interpretacji tych miejsc S. J. Gathercole wykazuje, że wszystkie one mówią o preegzystencji Jezusa Chrystusa i prowokują pytanie: „skąd tak naprawdę przyszedł?” Jezus z Nazaretu, na które jedyną odpowiedzią jest: „z nieba”"20. Co kryje się jednak pod pojęciem preegzystencji Jezusa? ${ }^{21}$

${ }^{18}$ Na ten temat odsyłam do monografii: E. Manicardi, dz. cyt., s. 148-170.

${ }^{19} \mathrm{Na}$ ten temat por. D. Kotecki, Misja Jezusa w Ewangelii wedtug św. Marca, „Theologica Thoruniensia” 5 (2004), s. 31-52.

${ }_{20}$ S. J. Gathercole, The Preexisten Son. Recovering the Cristologies of Matthew, Mark, and Luke, Grand Rapids-Cambridge 2006, s. 148-176.

${ }^{21}$ To pytanie jest o tyle uzasadnione, że istnieją teksty $\mathrm{w}$ formie przypominające te z Mk 1,24; 2,17; 10,45, tj. forma erchomai z bezokolicznikiem, wskazującym 
Wydaje się, że odpowiedź na to pytanie znajduje się zarówno w przytaczanej już cytacji 1,2-3, która wskazuje na uczestnictwo Jezusa w boskiej tożsamości Boga, jak i w pojawiającej się w narracji deklaracji głosu z nieba: „Ty jesteś mój Syn umiłowany, w Tobie upodobałem sobie” $(1,11)$.

\section{JEZUS ZOBACZYŁ $(1,10)$}

Ewangelista nie zatrzymuje się długo na samym chrzcie, ale szybko przechodzi do teofanii ${ }^{22}$. Nie jest ona efektem chrztu. Składają się na nią wizja i audycja ${ }^{23}$. Wizja, którą przeżywa sam Jezus (por. 1. poj. w eiden) ${ }^{24}$, następuje natychmiast (eutchys) po Jego wyjściu z wody ${ }^{25}$. Wizja zatem nie jest równoczesna z przyjęciem chrztu przez Jezusa. Wychodzenie Jezusa z wody (anabainō ek tou hydatos) i tym samym wchodzenie na brzeg (miejsce wyżej położone) może mieć znaczenie naturalne. Nie jest jednak wykluczone, że w kontekście całej Ewangelii to wychodzenie Jezusa może zawierać w sobie pewną myśl teologiczną. Jezus jeszcze dwa razy jest podmiotem orzeczenia wyprowadzonego od czasownika anabainō $(3,13 ; 6,51)$. W tych dwóch przypadkach chodzi o fizyczne wchodzenie na miejsce wyżej położone (odpowiednio: na górę, do łodzi). W 10,32.33 czasownik anabaino występuje w liczbie mnogiej i określa czynność Jezusa i Jego uczniów: wspólne wstępowanie do Jerozolimy, miejsca męki,

na cel misji, które odnoszą się do aniołów, proroków (por. S. J. Gathercole, dz. cyt., s. 83-147).

${ }^{22}$ S. Légasse, dz. cyt., s. 74, zwraca uwagę, że w opisie chrztu ewangelista używa tylko siedmiu słów greckich, natomiast $\mathrm{w}$ opisie teofanii aż trzydziestu czterech. Z tego wyprowadza wniosek, że cała narracja zatrzymuje się przede wszystkim na teofanii.

${ }^{23}$ Nie widzę powodu, aby nie traktować audycji jako części teofanii, tak np. J. Czerski, Metody interpretacji Nowego Testamentu, „Opolska Biblioteka Teologiczna” 21, Opole 1997, s. 112. Użycie aorystów eiden $(1,10)$ i egeneto dopełnionego przez phōnē sugeruje, że wizja i audycja stanowią jedną całość w sensie zarówno czasowym, jak i treściowym.

${ }^{24} \mathrm{~W}$ Mt zarówno wizja, jak i audycja są prawdopodobnie adresowane także do Jana Chrzciciela. Głos z nieba nie mówi bowiem: „Tyś jest... (sy ei)”, ale „Ten jest... (houtos estin)" (Mt 3,17), cała zaś scena rozgrywa się między Janem i Jezusem. W tradycji Janowej adresatem wizji jest sam Jan Chrzciciel (por. J 1,32).

${ }^{25} \mathrm{Na}$ określenie czynności wychodzenia autor używa imiesłowu czasu teraźniejszego anabainōn $\mathrm{z}$ wyrażeniem przyimkowym ek tou hydatos. Może chodzić tutaj zarówno o wynurzenie z wody, jak i wyjście z wody na brzeg. To nie jest jednak takie ważne. Najważniejsze jest to, że ewangelista wyraźnie oddziela wizję od chrztu. Por. A. Malina, dz. cyt., s. 238. 
śmierci i zmartwychwstania Jezusa. Mk 10,33 zawiera w sobie trzecią zapowiedź męki, śmierci i zmartwychwstania, po której po raz trzeci następuje niezrozumienie ze strony uczniów. W odpowiedzi na nie Jezus, mówiąc o swojej i ich śmierci, posługuje się terminologią chrzcielną $(10,38.39)$. Nie jest zatem wykluczone, że w użyciu przez Marka w scenie chrztu tego czasownika jest zawarta głęboka myśl, że oto rozpoczyna się Jezusowa droga wstępowania do Jerozolimy, gdzie przyjmie On chrzest innego rodzaju (mękę i śmierć), który jest widziany jako „okup za wielu” $(10,45)^{26}$. To ostatnie wyrażenie (gr. lytron anti pollōn) wskazuje na znaczenie ekspiacyjne i zbawcze śmierci Jezusa. To dzięki tej śmierci ludzie zostaną uwolnieni z niewoli grzechu i śmierci, z której sami wyzwolić się nie mogą. Do tego momentu są oni niewolnikami grzechu i śmierci, tzn. są w stanie, który wyklucza ich komunię z Bogiem. W tym kontekście owe wychodzenie Jezusa z wody można uznać za dopełnienie obrazu solidarności Jezusa z grzesznikami, wyrażonego w samym akcie chrztu. Z perspektywy całej Ewangelii staje się jasne, do jakiego stopnia w życiu Jezusa ta solidarność z grzesznikami dochodzi.

Na samą wizję składają się dwa elementy: rozwarcie się nieba i zejście Ducha Świętego w postaci gołębicy. Adresatem wizji jest sam Jezus. Podmiotem orzeczenia eiden (,ujrzał, zobaczyl”) w Mk jest tylko Jezus $(1,16.19 ; 2,14 ; 6,34)$. We wszystkich tych miejscach Jezus dostrzega coś, co jest zakryte przed innymi. Jest to akt doskonałego widzenia rzeczy takimi, jakimi są naprawdę.

Pierwszą widzianą rzeczywistością jest rozdarcie nieba (schidzomenous tous ouranous). Czynność rozdarcia jest wyrażona w stronie pasywnej, która może wskazywać na obecność passivum theologicum (sam Bóg jest podmiotem czynności rozdzierania). Można na nią spojrzeć jako na typowy element teofanii ${ }^{27}$, która domagała się otwarcia nieba pojmowanego jako mieszkanie Boga. Ten element może wskazywać również na interwencję Boga w celach zbawczych i bądź sygnalizuje sąd Boży, bądź przygotowuje zejście rzeczywistości niebiańskich ${ }^{28}$. Wielu badaczy patrzy na ten tekst w kontekście modlitwy z Iz 63,19 (TM) skierowanej do JHWH, aby Ten: „rozdarł niebiosa i zstąpił”29. To, co jest zapowie-

${ }^{26}$ Por. Tamże, s. 241.

${ }^{27}$ Po odpowiednie teksty odsyłam do: S. Légasse, dz. cyt., s. 74, przypis 11.

${ }^{28}$ Por. J. Czerski, Jezus Chrystus, s. 59.

${ }^{29}$ Por. R. A. Guelich, Mark 1-8,26, WBC 34a, Dallas 1989, s. 32. W TM mamy użyty czasownik $q r^{\prime}$, któremu w grece odpowiada schidzein. LXX używa w tym miejscu czasownika anoigein, co może sugerować, że Marek mógł opierać się na tekście hebrajskim. 
dziane w ST, realizuje się w pełni na Jezusie. Jak słusznie zauważa A. Malina, obraz rozdzieranych niebios jest absolutnym hapax legomenon w obydwu częściach Biblii greckiej. Porównuje go do obrazu rozdzieranych szat (niebo jest porównywane do tkaniny czy namiotu, np. w Iz 40,22; Ps 104,2), który w świecie semickim i grecko-rzymskim wyrażał smutek oraz wzburzenie $\mathrm{z}$ powodu bolesnych przeżyć. W takim kontekście obraz można interpretować w sensie metaforycznym: rozdzieranie nieba ukazuje uczucia samego Boga, spowodowane grzesznością ludzi. Jezus jest tym, który poznaje to, co Bóg odczuwa z powodu grzechów ludzi ${ }^{30}$. Samego czasownika schidzein używa Marek jeszcze tylko jeden raz $(15,38)$. W chwili śmierci Jezusa zostaje rozdarta (eschisthēn) zasłona przybytku, która była obrazem samego Boga. A. Malina zauważa: „Jak ludzie rozdzierali szaty wobec śmierci najbliższych, tak Bóg, rozdzierając to, co jest obrazem Jego samego i oznacza najwyższy stopień w hierarchii świętości, widoczny dla Izraelitów przebywających w świątyni, wyraża swój ból z powodu gwałtownej śmierci Syna"31.

W kontekście sceny cel rozdarcia nieba jest jasny: rozdarcie nieba wskazuje na pochodzenie Ducha w postaci gołębicy, jak i pozwala na jego ukazanie się ${ }^{32}$. Jeżeli przyjęlibyśmy, że w imiesłowie schidzomenous mamy do czynienia z passioum theologicum, znaczyłoby, że to sam Bóg otwiera niebo, aby zainterweniować. „Rozdarte niebo” jest dopełnieniem bliższym orzeczenia eiden, co ukazuje, że między Jezusem i rzeczywistością niebiańską nie ma żadnej bariery, nie ma nic, co oddzielałoby Jezusa od Boga. Takie stwierdzenie staje się zrozumiałe w kontekście tego, co powiedzieliśmy już o Mk 1,2-3. Jezus w pełni jest uczestnikiem boskiej tożsamości samego YHWH. Bóg w ten sposób będzie mógł w pełni zwrócić się do Jezusa. Gdybyśmy przyjęli znaczenie metaforyczne obrazu rozdzierania nieba, to na zstępowanie Ducha można by spojrzeć jako na odpowiedź Boga na grzechy ludzi. Duch zstępuje na Tego, który będzie chrzcił w Duchu Świętym, skutkiem zaś tego chrztu jest odpuszczenie grzechów. Jezus poznaje więc, że tylko On otrzymuje moc, która umożliwi Mu naprawę relacji między ludźmi i Bogiem.

${ }^{30}$ A. Malina, dz. cyt., s. 251-252.

${ }^{31}$ Tamże, s. 253. Nie jest przekonująca argumentacja "contra" zaproponowana przez S. Légasse, który uważa, że jest mało prawdopodobne przypisanie przez autora uznającego transcendencję Boga czynności tak materialnej jak rozerwanie zasłony przybytku (por. tenże, dz. cyt., s. 831, przypis. 48).

${ }^{32}$ Tak F. Lentzen-Deis, dz. cyt., s. 280. 
Duch Święty zstępuje (katabainon) w postaci jakby gołębicy ${ }^{33}$. Samo zstąpienie przypomina teksty Iz 11,2; 42,1 czy 61,1. Duch Boży zstępuje na Jezusa. Jezusowemu anabainōn (,wychodząc") odpowiada katabainon („zstępującego") Ducha Świętego ${ }^{34}$. W tym momencie mamy niejako skrzyżowanie dwóch linii, o których wspominał Ch. Schönborn. Nie oznacza to, że przed tym wydarzeniem Jezus był pozbawiony Ducha Świętego. Nie wydaje się konieczna interpretacja wyrażenia ,jak gołębica" w kluczu symbolicznym, odwołującym się do różnych obrazów ST i literatury judaistycznej ${ }^{35}$. Ten obraz powinien być interpretowany w kontekście całej wizji. Trzy przesłanki - 1. Gołębica reprezentuje Ducha Świętego; 2. Skierowuje się na Jezusa; 3. Przez partykułę ōs zostaje zaprezentowane jako widzialne to, co jest niewidzialne - sugerują, że nie należy zatrzymywać się zbytnio na tej figurze. Nie wydaje się dziwne, że ewangelista posłużył się postacią gołębicy. Ptaki były stworzeniami należącymi do ouranos (nieba) i tylko one mogły pokonać przestrzeń między niebem i ziemią. Nie było chyba lepszego ptaka, który mógłby reprezentować Ducha Świętego, od gołębicy, łączonej zarówno w ST, jak i literaturze Azji Mniejszej oraz Grecji z rzeczywistością boską $a^{36}$.

Duch Święty zstępuje eis auton (dosłownie: „w Niego"). Ewangelista często używa zamiennie przyimków en $\left({ }_{,}, \mathrm{w}^{\prime \prime}\right)$ i eis (,w kierunku”). Nie jest jednak wykluczone, że w tym przypadku chce podkreślić, że Duch Święty schodzi w Niego. Jezus staje się celem zstępowania Ducha. W ten sposób zostaje podkreślona szczególna więź między Jezusem a Duchem Świętym. W kontekście Janowej zapowiedzi przyjścia silniejszego od niego, który będzie chrzcił Duchem Świętym, staje się jasne, że nadszedł

${ }^{33}$ Marek używa tutaj terminu to pneuma bez żadnej specyfikacji (Mt 3,16 mówi o Duchu Boga, to pneuma tou theou; Łk zaś o Duchu Świętym - to pneuma to hagion). Kontekst (por. 1,8) sugeruje, że chodzi o Ducha Świętego.

${ }_{34}$ Por. R. A. Guelich, dz. cyt., s. 31.

${ }^{35}$ Po wykaz różnych interpretacji symbolicznych odsyłam do: F. Lentzen-Deis, dz. cyt., s. 170-183; S. Légasse, dz. cyt., s. 75-76. Wśród tych interpretacji najbardziej znane są nawiązujące: 1 ) do opowiadania o potopie (Rdz 8,8n); 2) do opisu stworzenia (Rdz 1,2) - w komentarzach rabinistycznych Duch, który unosił się nad wodami, jest porównany do gołębicy; 3) do Oz 7,11, który porównuje Izraela do gołębia; 4) do Ps 56,1; 68,12-14; Pnp 1,15; 4,1 i tematów mitologicznych - widzą w gołębicy „posłańca miłości"; 5) do interpretacji judaistycznej chwały Bożej (szekina) jako gołębicy.

${ }^{36}$ Por. H. Greeven, peristera, w: Theologisches Wörterbuch zum Neuen Testament, Stuttgart-Berlin-Köln 1990 (dalej: TWNT), t. 6, s. 63-72; J.-A. Bühner, peristera, w: Exegetisches Wörterbuch zum Neuen Testament, Stuttgart-Berlin-Köln 1992, t. 3, kol. 184-186; D. Forstner, Świat symboliki chrześcijańskiej, Warszawa 1990, s. 228-232. 
czas realizacji zapowiedzi. Jezus będzie mógł chrzcić w Duchu Świętym, ponieważ posiada $\mathrm{w}$ pełni Tego Ducha ${ }^{37}$. Następujące po wydarzeniu chrztu narracje będą pokazywały, że Jezus działa w Duchu Świętym ${ }^{38}$.

\section{3. "TY JESTEŚ MÓJ SYN UMIŁOWANY" (1,11B)}

Cała wizja zostaje wyjaśniona przez audycję skierowaną tylko do Jezusa (inaczej w 9,7): „Ty jesteś mój Syn umiłowany, w Tobie upodobałem sobie" $(1,11 b)$. Normalna sekwencja wydarzeń powinna być następująca: Jezus zobaczył i usłyszał. W naszym przypadku ewangelista nie mówi nic o czynności usłyszenia. W całej Ewangelii Marka Jezus ani razu nie jest podmiotem orzeczenia wyprowadzonego od czasownika słyszeć (akouein). W ST taki akt towarzyszył prorokom (por. Iz 6,8; Ez 1,28). Oni, zanim przekazali Słowa Pana, zawsze je słyszeli. To - wydaje się - celowe pominięcie aktu słyszenia, przedstawia Jezusa jako tego, który doskonale poznaje, odkrywa rzeczy takimi, jakimi są naprawdę (por. 2,8-10; 5,30; 9,33-50) ${ }^{39}$. Takie poznanie nie towarzyszy żadnemu człowiekowi.

Pochodzenie głosu ek tōn ouranōn (,z niebios") jednoznacznie wskazuje na Boga. Nie jest to bat-qôl (,"córka głosu” $)^{40}$, która w literaturze rabinicznej i apokaliptycznej była utożsamiana z echem głosu Bożego, wprowadzającego obietnicę zbawienia dla pojedynczych osób ${ }^{41}$. W naszym przypadku Bóg zwraca się bezpośrednio do Jezusa: „Ty jesteś mój Syn umiłowany, w Tobie upodobałem sobie" $(1,11)$.

W ST oraz w literaturze judaistycznej tytuł "Syn Boży" był odnoszony do aniołów (por. Rdz 6,2; Hi 1,6; 2,1; 38,7; Ps 29,1), do Izraela

${ }^{37}$ Pozostali synoptycy mówią o zejściu Ducha na Jezusa: ep’auton (Mt 3,16; Łk 3,22). Koncept Marka zdaje się bardziej zbliżony do myśli Jana, który mówi o pozostawaniu Ducha na Jezusie: emeinen ep'auton $(1,31)$. Zastosowane tutaj orzeczenie od czasownika menein wskazuje na nieustanne posiadanie Ducha przez Jezusa, który w ten sposób może Go dać innym, co ma miejsce w czasie Jego śmierci $(19,30.34)$ oraz po Jego zmartwychwstaniu (20,22); por. D. Kotecki, Duch Święty jako dar Jezusa w Ewangelii wedtug św. Jana, w: Przybliżyło się Królestwo Boże, Fs. R. Bartnicki, red. W. Chrostowski, Warszawa 2008, s. 240-257.

${ }^{38}$ Na całą działalność Jezusa można spojrzeć jako na chrzczenie w Duchu Świętym: por. A. Malina, dz. cyt., s. 232-237 („Ekskurs 6. Działalność Jezusa jako chrzczenie w Duchu Świętym").

${ }^{39}$ Por. tamże, s. 264.

${ }^{40}$ Utożsamienie głosu z nieba z bat qôl prezentuje m.in. V. Taylor, dz. cyt., s. 161.

${ }^{41} \mathrm{Na}$ temat bat qôl odsyłam do: O. Betz, phon $\square$, w: TWNT, t. 9, s. 281-283. 
(Wj 4,22; Pwt 14,1; Oz 2,1; 11,1; Iz 1,2; 30,1), niektórych sędziów (Ps 82,6), człowieka sprawiedliwego (Syr 4,10; Mdr 2,18) czy do króla Dawidowego (2 Sam 7,14; Ps 2,7; 89,27) ${ }^{42}$. Ten tytuł mówił o szczególnym wybraniu czy misji. W takim kontekście również Jan Chrzciciel mógł być tak nazwany. Tytuł ten nabiera jednak zupełnie nowego znaczenia w 1,11. Zostaje zaakcentowana intensywna wzajemna relacja między Jezusem i Bogiem. W deklaracji występują formy czasownikowe i zaimki w pierwszej i drugiej osobie liczby pojedynczej: ei (,,jesteś”), eudokēsa („,upodobałem”), sy („ty”), mou („mój”), soi („,sobie”), które podkreślają tę intymną relację. Dodatek przymiotnika „umiłowany” (agapètos) wskazuje na pierwszym miejscu na serdeczną więź uczuciową z osobą określaną w ten sposób. Jezus jest pierwszym umiłowanym, Bóg zaś pierwszym miłującym. W grece świeckiej, jak i kilkakrotnie w LXX ten przymiotnik staje się synonimem terminu ,jedyny" (monogenēs) ${ }^{43}$, co oznacza, że nikt inny nie znajduje się w takiej relacji do Boga jak Jezus. Jest On jedyny w swoim rodzaju (mono genous). „Ta jedyność Synostwa Bożego Jezusa oznacza, że jest On Bogiem"44. Ewangelista w pierwszym wierszu swojego dzieła także deklaruje, że Jezus jest Mesjaszem i Synem Bożym. Tutaj jednak deklaracja $z$ nieba odsłania tożsamość samego Boga: On jest miłującym Ojcem. W scenie przemienienia Bóg również objawia uczniom samego siebie w relacji do Jezusa („,To jest mój Syn umiłowany”) i wzywa ich do słuchania Swojego Syna $(9,7)$.

Na końcu zostaje dodane: „w tobie upodobałem sobie” (en soi eudokēsa). Treść tego głosu nawiązuje do Iz 42,1: „Oto mój Sługa, którego podtrzymuję. Wybrany mój, w którym mam upodobanie”. W tym tekście hebrajskie rātstâh i nafshî w greckiej wersji Symmacha i Teodocjona są tłumaczone jako eudokēsa (LXX: prosedeksato auton hē psychē mou). Czasownik eudokēo w odniesieniu do Boga podkreśla ideę wybrania i misji. Tylko Jezus został wybrany i tylko Jemu została powierzona decydująca

${ }^{42}$ Por. E. Lohse, hyios, w: TWNT, t. 8, s. 358-361. Po szkice na temat obrazu Jezusa jako Syna Bożego odsyłam do: J. Czerski, Ewangelie synoptyczne w aspekcie literackim, historycznym i teologicznym, „Opolska Biblioteka Teologiczna” 12, Opole 1996, s. 101-105; S. J. Gathercole, dz. cyt., s. 272-283; G. O'Collins, Christology. A Biblical, Historical and Systematic Study of Jesus, Oxford 2009, s. 119-140; H. Langkammer, Obraz Jezusa Chrystusa w świetle Nowego Testamentu, Rzeszów 2009, s. 89-111.

${ }^{43}$ W LXX przymiotnik ten występuje dwadzieścia dwa razy, z czego sześć razy ( $\operatorname{Rdz} 22,2.12 .16$; Sdz 11.34; Am 8,10; za 12,10) jest tłumaczeniem hebrajskiego yahid ,jedyny".

44 J. Czerski, Jezus Chrystus, s. 60. 
misja (por. 12,6). Nie oznacza to, że Jezus stał się umiłowanym Synem Boga, został wybrany i posłany na misję w momencie chrztu w Jordanie. Głos z nieba jest tylko proklamacją godności, którą Jezus miał od samego początku (por. aoryst eudokēsa, który odnosi się do czynności już wypełnionej). Mowa jest zatem o odwiecznej miłości między Ojcem i Synem.

Podsumowując, można powiedzieć, że do Jana, aby przyjąć od niego chrzest, przychodzi Ten, w którym nie ma żadnego braku Jego relacja do Boga, ponieważ jest uczestnikiem jedynej boskiej tożsamości. Nie przez przypadek ewangelista na samym początku umieszcza cytat (1,2-3), sugerujący boską tożsamość Jezusa i należący do tych miejsc w NT, które aplikują do Jezusa starotestamentowe teksty, używające imienia Bożego. Tę prawdę kontynuuje podkreślenie przez ewangelistę bezgrzeszności Jezusa. $Z$ tego też powodu może on chrzcić w Duchu Świętym, tzn. odpuszczać grzechy, co może być tylko dziełem Boga (por. 2,7; 3,28; 11,25). Przyjście Jezusa staje się wypełnieniem Janowego przepowiadania o przyjściu silniejszego od niego $(1,7)$. Jednocześnie jednak ewangelista akcentuje ziemskie pochodzenie owego silniejszego od Jana. Jest to Jezus z Nazaretu Galilejskiego $(1,9)$. Jest to Ktoś, kto ma swoją ziemską historię. Kluczem do zrozumienia tajemnicy Jezusa wydaje się wspomniana na samym początku idea samouniżenia się Boga. W Jezusie przecinają się dwie linie: samouniżenie się Boga i wywyższenie człowieka. Jezus, który uczestniczy w tożsamości samego Boga (Jego relacja do Boga jest doskonała), przyjmując chrzest w Jordanie, pokazuje swoją solidarność z tymi, którzy uznają swoją relację do Boga za niewłaściwą (są grzesznikami). Historyczny Jezus z Nazaretu to Syn umiłowany, jedyny Boga. Wydaje się, że ewangelista $\mathrm{w}$ opisie wydarzenia chrztu zawarł przekonanie pierwszych chrześcijan, wyrażone chociażby w Flp 2,6-11, gdzie św. Paweł ukazuje preegzystującego Jezusa, równego Bogu, uczestniczącego w chwale niebiańskiej („On istniejąc w postaci Bożej”: $2,6)$, jako Tego, który „w zewnętrznym przejawie uznany za człowieka” (Flp 2,7b) przyjął postać sługi (wcielenie), stając się posłuszny aż do śmierci krzyżowej (śmierć odkupieńcza). Scena chrztu jest preludium do całej działalności Jezusa. On, Jezus z Nazaretu, osadzony w swojej ludzkiej historii (tajemnica wcielenia), jest jednocześnie uczestnikiem boskiej tożsamości samego Boga (preegzystencja). Przyjmując chrzest w Jordanie, którego nie potrzebował, staje się sługą grzeszników. Ta Jego solidarność z grzesznikami znajdzie swój finał w innym chrzcie, tj. w Jego męce i śmierci krzyżowej (por. 10,38), w której w pełni objawi się jako Syn Boży $(15,39)$. W opisie tego wydarzenia można odnaleźć 
wiele elementów paralelnych do opisu chrztu w Jordanie: tylko w tych dwóch opisach występuje czasownik schidzein w stronie pasywnej, który odnosi się odpowiednio do niebios $(1,10)$ i zasłony przybytku $(15,38)$; w obydwu scenach mamy twierdzenia odnoszące się do tożsamości Jezusa, odpowiednio: „Ty jesteś mój Syn umiłowany, w Tobie upodobałem sobie" $(1,11)$ oraz "Zaprawdę, ten człowiek był Synem Bożym” $(15,39)$; w jednym i drugim przypadku mówi się o niezwykłym głosie, odpowiednio „z nieba” $(1,11)$ i Jezusa („zawołał Jezus wielkim głosem”: 15,34), który wprowadza do wypowiedzi ukazującej głęboką relację między Bogiem i Jezusem („Ty jesteś mój Syn umiłowany”: 1,11; „Boże mój, Boże mój”: 15,34). To są tylko niektóre elementy paralelne. Ten paralelizm nie wydaje się przypadkowy. Być może ewangelista chciał, aby na obydwa wydarzenia spojrzeć w tym samym kluczu. Nie znajduję lepszego klucza do ich interpretacji niż idea samouniżenia się Boga. Śmierć Jezusa pokazuje, do jakiego stopnia Bóg uniżył samego siebie.

\section{THE BAPTISM OF JESUS IN MARK'S GOSPEL (1:9-11) AND THE IDEA OF SELF-HUMILIATION OF GOD. CONTRIBUTION TO CHRI- STOLOGY OF MARK'S GOSPEL}

\section{SUMMARY}

The author of this paper delivers an exegesis of Mark 1:9-11. In his view, the key to a full understanding of the baptism in the Jordan is the idea of selfhumiliation of God. Read in a literary context, the narrative of Jesus's baptism in the Jordan contains features that indicate the presence of this idea.In Jesus, who is seen both within his specific Earthly story ("In those days Jesus came from Nazareth in Galilee"; Mk 1:9) and as a partaker in the nature of God (Mk 1:2-3), two themes intersect: the self-humiliation of God and the exaltation of man. Being a partaker in the nature of God, and perceived in perfect relationship to Him (untainted by sin), Jesus Christ demonstrates his solidarity with sinful mankind by accepting the baptism intended for sinners.The scene of Jesus's baptism in the Jordan is a narrative prelude to the entire Christology that culminates in His death (15:33-39), which in itself is seen as a different kind of baptism for Jesus (cf. 10:38). This event answers the question of how deeply God has humiliated Himself. 